\title{
VIGILANCIA TÉCNOLÓGICA DE NO TEJIDOS A BASE DE NYLON-6 PRODUCIDOS POR ELECTROSPINNING PARA USO EN ENTORNOS HOSPITALARIOS.
}

\section{TECHNICAL SURVEILLANCE OF NON-WOVEN BASED ON NYLON-6 PRODUCED BY ELECTROSPINNING FOR USE IN HOSPITAL ENVIRONMENTS.}

\author{
Ing. ${ }^{1}$ M. L. Mejía, Ing. ${ }^{2}$ J. Zapata, PhD. ${ }^{3}$ D. P Cuesta, PhD. ${ }^{4}$ I.C. Ortiz, PhD. ${ }^{5}$ L.E. \\ Botero, MSc. ${ }^{6}$ B. J. Galeano, MSc. ${ }^{7}$ N. J Escobar, PhD. ${ }^{8}$ L. M. Hoyos. \\ *Universidad Pontificia Bolivariana, Facultad de Ingeniería, ${ }^{1,2,6,7,8}$ Grupo de \\ bioingeniería, ${ }^{3}$ Grupo de Salud Pública, ${ }^{4,5}$ Grupo de biología de sistemas. \\ Circular 1 No.73-76 bloque 22 C, Medellín, Antioquia, Colombia. \\ Teléfono y Fax, con indicativos internacional y nacional. \\ ${ }^{1}$ Email: monica.mejias@upb.edu.co
}

\begin{abstract}
Resumen: En esta investigación, se considera la vigilancia tecnológica de las nanofibras no tejidas a base de Nylon-6 producidas por electrospinning, diferentes parámetros sobre el proceso de electrospun (concentración, voltaje, distancia de punta a colector de aguja y caudal), fueron analizados para su aplicación en entornos hospitalarios. Se encontró que el Nylon 6 presenta buenas propiedades mecánicas, biocompatibilidad y eficiencia como filtros de agua que permite su uso en un proceso de electrospinning para desarrollar nanofibras no tejidas con porosidad, gran área superficial por unidad de masa y alta permeabilidad, lo que lo hace un material opcional para entornos hospitalarios. La variación de los parámetros de electrospinning favorece la conformación de nanofibras no tejidas, reduce las gotas y proporciona diámetros de nanofibras más pequeños.
\end{abstract}

Palabras clave: Nylon-6, no tejido, nanofibra, nanotextil, electrospinning, entornos hospitalarios.

\begin{abstract}
In this research, we consider about the technological surveillance of nonwoven nanofibers based on nylon-6 produced via electrospinning, different parameters about the process of electrospun (concentration, voltage, needle tip-to-collector distance, and flow rate), were analyzed for their application in hospital environments. We found that Nylon 6 exhibits good mechanical properties, biocompatibility, and efficiency as water filters that permits their use in a process of electrospinning to develop non-woven nanofibers with porosity, large surface area per unit mass, and high permeability, it makes a good option material for hospital environments. The variation of electrospinning parameters favors the conformation of non-woven nanofibers, reduce the drops, and provides smaller nanofiber diameters.
\end{abstract}

Keywords: Nylon-6, non-woven, nanofiber, nanotextil, electrospinning, hospital environments. 


\section{INTRODUCTION}

According to International Standard ISO 9092, non-woven textiles are defined as a manufactured sheet, veil or fiber material oriented in a direction or randomly joined by chemical or thermal mechanical processes. The fibers may be continuous or discontinuous fibers, or be formed in situ (ICONTEC 1996). Non-wovens are porous and flexible products, consisting of one or more layers of fibers. Non-woven textiles can be classified as single use disposables (diapers, medical dressings, household wipes and protective clothing) or durable (the interface of clothing, automobile headliners and carpets)(Abu Sayed 2017).

Nanotechnology in non-woven textiles can improve properties to benefit textile processing; For example, adhesive properties, antibacterial properties, energy production (for solar energy) and luminescence (for color control)(Haydon 2013). Non-woven nanofibers can be developed with polymers of natural or synthetic origin, among them it's found the Nylon 6.

Nylon-6, also known as polyamide 6, is a biodegradable, biodegradable synthetic polymer material and has good mechanical properties, such as its hardness, elasticity, toughness and resistance to abrasion, wear, oils, heat, resistance chemistry and easy processing capability. It is used in automobile parts, wipes, battery separators, synthetic suede, brush bristles and protective garments (Ryu et al. 2003). The most commonly used techniques for producing non-woven fibers in general include Meltblown process, multicomponent process and electrospinning(Raj et al. 2011; H. R. Pant et al. 2011; Gieseking et al. 2012; Montazer and Malekzadeh 2012; Ryu et al. 2003).

The technique of electrospinning "electrostatic spinning" or "electrospun" is a method of manufacturing scaffolds composed of continuous non-woven fibers (Braghirolli, Steffens, and Pranke 2014; Agarwal, Wendorff, and Greiner 2008; Joshi 2011). This technique has proven to be simple, versatile, cost-effective and reproducible (Montero et al. 2012; Okutan, Terzi, and Altay 2014; Y. Zhang et al. 2005; Kharaziha et al. 2013). The electrospinning process involves the use of an electric field to convert or melt a polymer solution into a fiber form (Y. Zhang et al. 2005; Zhuo, Hu, and Chen 2008). It consists of three main components: a high voltage source with a positive and negative polarity that guarantees a continuous electric field, an electrically conductive metal collector (usually a fixed aluminum plate, or a rotary drum), in which The resulting fibers and an pump to adjust the feed rate of the polymer solution contained in a syringe with a capillary or needle diameter of 0.1 to $1 \mathrm{~mm}$ (Montero et al. 2012; Sill and Recum 2008; Sun et al. 2013).

To achieve fiber deposition an electrical potential is applied between a drop of a polymer solution located at the end of the needle nozzle and a fixed or grounded metallic collector plate which serves as a counter-electrode, the Electro-silking is carried out by controlling temperature and humidity (Rogina 2014; Okutan, Terzi, and Altay 2014; Y. Zhang et al. 2005). Depending on the location and design in which the equipment is available, the produced nanofibers will be deposited vertically or horizontally. When the applied electric field exceeds the surface tension of the drop, it is deformed into a conical shape (Taylor's cone) and a stream of polymer solution, which is controlled by the electric field, is drawn into the collector. The jet becomes longer and thinner constantly, meanwhile, the solvent evaporates quickly. Finally the nanofibers are collected in the collector plate (Montero et al. 2012; Okutan, Terzi, and Altay 2014; Y. Zhang et al. 2005; Qin and Chronakis 2010)

Many parameters may influence the electrospinning process, including the properties of the solution (e.g., concentration, viscosity, electrical conductivity, surface tension and dielectric properties), which regulate the variables (e.g. electric force, flow rate, distance to the collector plate) and environmental parameters such as humidity and temperature. These directly affect the formation and structure of the fibers and may facilitate the presence of gout defects (Okutan, Terzi, and Altay 2014)(Chong et al. 2007).

The electrospinning processes allow the production of nanofibers with a diameter of less than $500 \mathrm{~nm}$ (Raj et al. 2011; H. R. Pant et al. 2011; Gieseking et al. 2012; Montazer and Malekzadeh 2012). The Nylon 6 nanofibers, produced by electrospinning are practical, efficient, with high surface relation, under electric field, with spiderlike appearance, hard, elastic and with gloss( $\mathrm{Li}$, Huang, and Lü 2006; S. Zhang, Shim, and Kim 2009; Kim et al. 2013), these have been reported as an effective means of water filtration due to their porosity (Raj et al. 2011; H. R. Pant et al. 2011). 


\section{METHODOLOGY}

A technological surveillance was developed using the search equation with the terms "non-woven" and "electrospinning" and "nano" through the use of the Scopus database, these contains the largest bibliographical references of scientific literature, with over 18,000 titles from 5,000 international publishers (ELSEVIER 2017). The term "nonwoven", and the term "electrospinning" and the term "nano" produces 132 results, between 2005 and 2017.

\subsection{Documents per year}

Between 2005 and 2017 (Fig. 1) there is a production of 132 papers, with 2011 being the year with the highest number of publications (SCOPUS 2017).

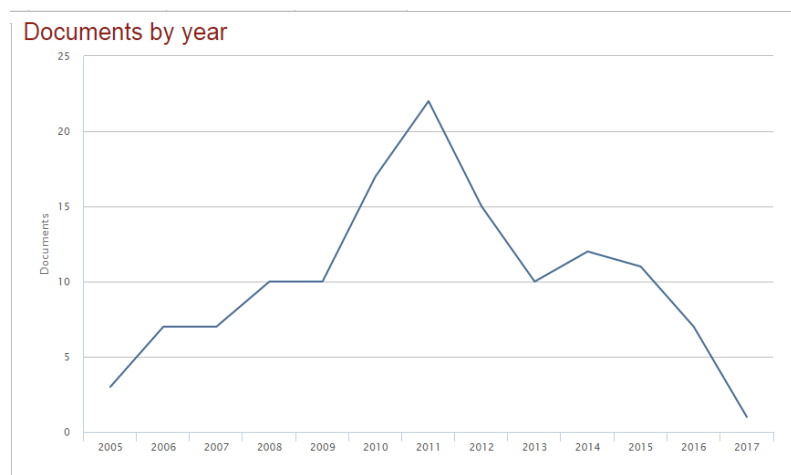

Fig. 1. Documents per year (SCOPUS 2017).

\subsection{Documents by subject area}

Between 2005 and 2017 (Fig. 2) has increased the diversity of areas in which the non-woven presents applications, mainly materials science, engineering, chemistry, chemical engineering and others (SCOPUS 2017, Moreno et al., 2013).

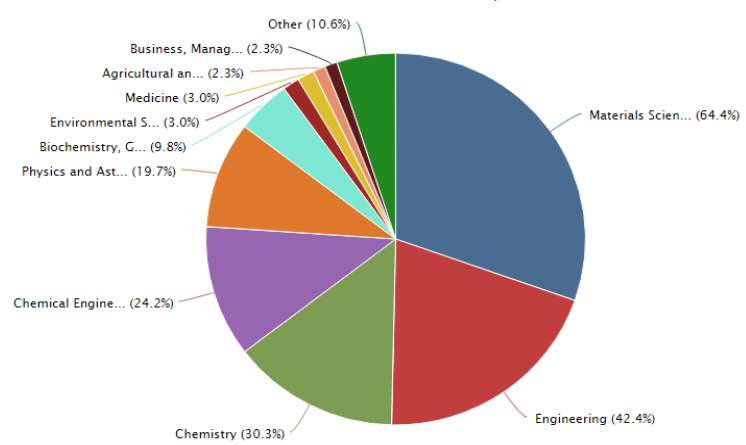

Fig. 2. Documents by subject area (SCOPUS 2017).

\subsection{Electrospinning parameters analyzed per author}

The technological surveillance is developed from the 10 authors with the largest number of publications on the subject of non-woven products produced by means of electrospinning for use in hospital environments because it is pertinent to consider the parameters of electrospinning to obtain more defined nanofibres, of smaller size, and with droplet reduction (TABLE I).

Table I. Electrospinning Parameters

\begin{tabular}{|c|c|}
\hline Parameters & $\begin{array}{l}\text { Effect on fiber } \\
\text { morphology }\end{array}$ \\
\hline \multicolumn{2}{|l|}{ Processing Parameters } \\
\hline$\overline{\text { Voltage applied } \uparrow}$ & $\begin{array}{l}\downarrow \text { diameter of the fiber } \\
\text { initially, then } \\
\text { diameter }\end{array}$ \\
\hline Flow rate $\uparrow$ & $\begin{array}{l}\uparrow \text { diameter of the fiber, } \\
\text { generation of drops } \\
\text { with very high speeds }\end{array}$ \\
\hline $\begin{array}{l}\text { Distance between the } \\
\text { nozzle and the } \\
\text { collector } \uparrow\end{array}$ & $\begin{array}{l}\downarrow \text { diameter of the fiber, } \\
\text { generation of drops } \\
\text { with distances or very } \\
\text { small or very large }\end{array}$ \\
\hline \multicolumn{2}{|l|}{ Solution Parameters } \\
\hline $\begin{array}{l}\text { Concentration } \\
\text { polymer } \uparrow\end{array}$ & $\uparrow$ diameter of the fiber \\
\hline $\begin{array}{l}\text { Molecular weight of } \\
\text { the polymer } \uparrow\end{array}$ & $\uparrow$ diameter of the fiber \\
\hline Viscosity $\uparrow$ & $\begin{array}{l}\uparrow \text { diameter of the fiber, } \\
\text { disappearance of drops }\end{array}$ \\
\hline \multicolumn{2}{|c|}{ Environmental Parameters } \\
\hline Humidity $\uparrow$ & $\begin{array}{l}\text { Circular pores in the } \\
\text { fibers }\end{array}$ \\
\hline Temperature $\uparrow$ & $\downarrow$ diameter of the fibers \\
\hline
\end{tabular}

\section{RESULTS AND DISCUSSION}

For the synthesis of non-woven nanofibres of Nylon 6 by means of electrospinning the following parameters were found used by several authors.

\subsection{Solution parameters}

The solvents used by the authors to dissolve the nylon 6 synthetic polymer are formic acid (Ryu et al. 2003; S. Zhang, Shim, and Kim 2009; Faccini, Vaquero, and Amantia 2012; H. R. Pant et al. 2010; Heikkilä et al. 2007; Montazer and Malekzadeh 2012; B. Pant et al. 2012; Shi et al. 2011; Park et al. 2009; Kim et al. 2013; Raj et al. 2011; H. R. Pant et al. 2011; Yin, Krifa, and Koo 2015) acetic acid (Faccini, Vaquero, and Amantia 2012; H. R. Pant et al. 2010; Montazer and 
Malekzadeh 2012; B. Pant et al. 2012; Kim et al. 2013; Raj et al. 2011; H. R. Pant et al. 2011), and 2,2,2-trifluoroethanol (TFE)(Li, Huang, and Lü 2006; Gieseking et al. 2012; Francis et al. 2010; Vitchuli et al. 2011)(Table II).

Table II. Solution Parameters

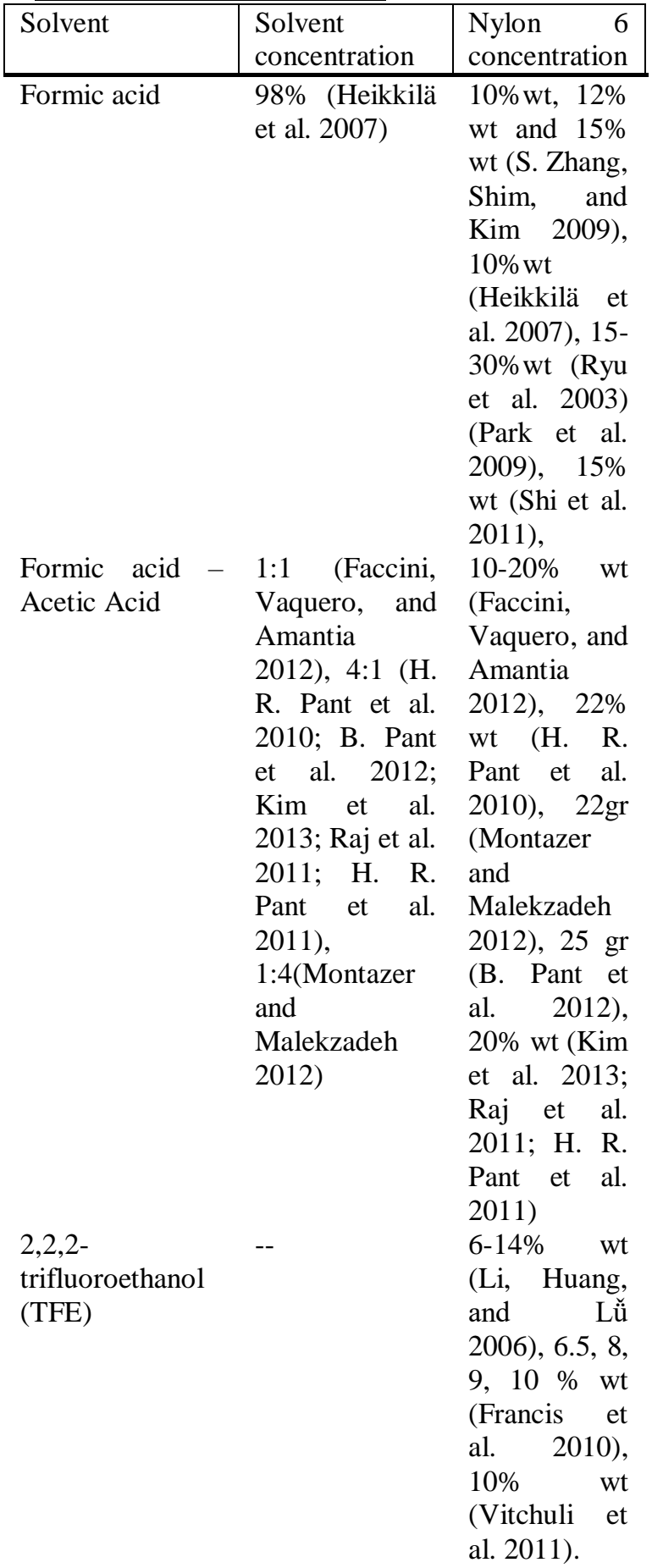

\subsection{Processing Parameters}

The electrospinning process parameters for the development of nonwoven nanofibers analyzed by different authors are applied voltage, flow velocity, and distance between the needle and the collector (TABLE III) (Ryu et al. 2003; S. Zhang, Shim, and Kim 2009; Faccini, Vaquero, and Amantia 2012; H. R. Pant et al. 2010; Heikkilä et al. 2007; Montazer and Malekzadeh 2012; B. Pant et al. 2012; Shi et al. 2011; Park et al. 2009; Kim et al. 2013; Raj et al. 2011; H. R. Pant et al. 2011; Yin, Krifa, and Koo 2015; Li, Huang, and Lü 2006; Gieseking et al. 2012; Francis et al. 2010; Vitchuli et al. 2011).

Table III Processing Parameters

\begin{tabular}{|l|l|}
\hline Processing Parameters & Value \\
\hline
\end{tabular}

Applied voltage

$8,12,15,18,20,21$, $22,25,30,32 \mathrm{kV}$

Flow velocity $0.1,0.3,0.5,0.8,1,1.5$ $\mathrm{ml} / \mathrm{h}$

Distance between the $5,6,10,14,15,16,18$, needle and the collector $20,25,30 \mathrm{~cm}$

\subsection{Environmental Parameters}

The environmental parameters (temperature and relative humidity) can influence the results of the formation of nanofiber non-woven, so a proper control must be performed (Table IV) (Ryu et al. 2003; S. Zhang, Shim, and Kim 2009; Faccini, Vaquero, and Amantia 2012; H. R. Pant et al. 2010; Heikkilä et al. 2007; Montazer and Malekzadeh 2012; B. Pant et al. 2012; Shi et al. 2011; Park et al. 2009; Kim et al. 2013; Raj et al. 2011; H. R. Pant et al. 2011; Yin, Krifa, and Koo 2015; Li, Huang, and Lü 2006; Gieseking et al. 2012; Francis et al. 2010; Vitchuli et al. 2011, Caballero A. et al., 2013).

Table IV. Environmental Parameters

\begin{tabular}{|l|l|}
\hline $\begin{array}{c}\text { Environmental } \\
\text { Parameters }\end{array}$ & Value \\
\hline Temperature & $22^{\circ} \mathrm{C}$ (Serbezeanu et al. \\
& $2015), \quad 25^{\circ} \mathrm{C} \quad(\mathrm{Li}$, \\
& Huang, and Lü 2006), \\
& Ambience (Ryu et al. \\
& $2003), \quad$ (Park et al. \\
& 2009). \\
\hline Relative humidity & Controlled (Francis et \\
& al. 2010). \\
\hline
\end{tabular}

\section{CONCLUSION}

For the development of a non-woven nanofiber 
based on Nylon-6, through the use of electrospinning, a technological surveillance was performed in which a large number of publications and areas were found around the subject, the influence they have been studied extensively the parameters in the electrospinning process, at a higher concentration or viscosity of Nylon-6 in the solution, lower distance between the nozzle and the collector, and higher flow velocity produces a smaller pressure normalized by the diameter of the larger sized fibers, droplet reduction. By varying the collection time, nanofibers are obtained with higher thickness and better air permeability. The diameter of the nanofibers decreases slightly with increasing tension, relative humidity and tip distance to needle collector, attributed to the rate of evaporation of the solvent during electrospinning. The efficiency of filtration increases with the decrease of concentration of the solution and the increase of the applied voltage.

\section{ACKNOWLEDGMENT}

The authors are especially grateful to Colciencias in the call for Science, Technology and Innovation in health 711-2015 under contract number 121071149742, for the financing of the research project and to the Universidad Pontificia Bolivariana, which is located in Medellín, for having the availability of study spaces and laboratories for its development.

\section{REFERENCES}

Abu Sayed. 2017. "What Is Non-Woven Fabric? Characteristics and Uses of Non-Woven Fabric." 2017. Accessed February 17.

https://textileapex.blogspot.com.co/2014/09/characteristicsuses-of-non-woven.html.

Agarwal, Seema, Joachim H. Wendorff, and Andreas Greiner. 2008. "Use of Electrospinning Technique for Biomedical Applications." Polymer 49 (26). Elsevier Ltd: 5603-21. doi:10.1016/j.polymer.2008.09.014.

Braghirolli, Daikelly I, Daniela Steffens, and Patricia Pranke. 2014. "Electrospinning for Regenerative Medicine: A Review of the Main Topics." Drug Discovery Today, April. doi:10.1016/j.drudis.2014.03.024.

Caballero Amaury, Velasco Gabriel, Pardo García A. (2013). DIFFERENTIATIONS OF OBJECTS IN DIFFUSE DATABASES. Revista colombiana de tecnologías de Avanzada. 2 (22). Pág. $131-137$.

Chong, E J, T T Phan, I J Lim, Y Z Zhang, B H Bay, S Ramakrishna, and C T Lim. 2007. "Evaluation of Electrospun PCL/gelatin Nanofibrous Scaffold for Wound Healing and Layered Dermal Reconstitution." Acta $\begin{array}{llll}\text { Biomaterialia } & 3 & \text { (3): } & 321-30 .\end{array}$ doi:10.1016/j.actbio.2007.01.002.

ELSEVIER. 2017. "Elsevier Bases de Datos." http://www.americalatina.elsevier.com/corporate/es/scopus. php.

Faccini, M., C. Vaquero, and D. Amantia. 2012. "Development of Protective Clothing against Nanoparticle Based on Electrospun Nanofibers." Journal of Nanomaterials 2012. doi: $10.1155 / 2012 / 892894$.

Francis, L., F. Giunco, A. Balakrishnan, and E. Marsano. 2010. "Synthesis, Characterization and Mechanical Properties of Nylon-Silver Composite Nanofibers Prepared by Electrospinning." Current Applied Physics 10 (4). Elsevier B.V.: 1005-8. doi:10.1016/j.cap.2009.12.025.

Gieseking, Björn, Berthold Jäck, Eduard Preis, Stefan Jung, Michael Forster, Ullrich Scherf, Carsten Deibel, and Vladimir Dyakonov. 2012. "Electrospun Ultrathin Nylon Fibers for Protective Applications." Polymers and Polymer Composites 21 (7): 449-56. doi:10.1002/aenm.201200304.

Haydon, Brian. 2013. Nanomaterials and Their Applications in Textiles, Standards: Domestic Standardization for Canadian Manufacturers and Importers and International.

Heikkilä, P, A Sipilä, M Peltola, A Harlin, and A Taipale. 2007. "Electrospun PA-66 Coating on Textile Surfaces." Textile Research Journal 77 (11): 864-70. doi:10.1177/0040517507078241.

ICONTEC. 1996. "NTC 3911."

Joshi, Mangala. 2011. "Nanotechnology: A New Route to High Performance Textiles." Textile Progress 43 (3): 272-93. doi:10.1080/00405167.2011.570027.

Kharaziha, Mahshid, Mehdi Nikkhah, Su-Ryon Shin, Nasim Annabi, Nafiseh Masoumi, Akhilesh K Gaharwar, Gulden Camci-Unal, and Ali Khademhosseini. 2013. "PGS:Gelatin Nanofibrous Scaffolds with Tunable Mechanical and Structural Properties for Engineering Cardiac Tissues." Biomaterials $\quad 34 \quad$ (27): $\quad$ 6355-66. doi:10.1016/j.biomaterials.2013.04.045.

Kim, Hanjoo, Hemraj Pant, Chan Hee Park, D Leonard, B O Sang Hwang, N A G Jung Choi, and Cheol Sang Kim. 2013. "Electrical Properties of ZnO/Nylon-6 Spider-Wavelike Nano-Netsprepared via Electrospinning." Digest Journal of Nanomaterials and Biostructures 8 (1): 385-93.

Li, Yan, Zhengming Huang, and Yandong Lü. 2006. "Electrospinning of Nylon-6,66,1010 Terpolymer." European Polymer Journal 42 (7): 1696-1704. doi:10.1016/j.eurpolymj.2006.02.002.

Montazer, M., and S. B. Malekzadeh. 2012. "Electrospun Antibacterial Nylon Nanofibers through in Situ Synthesis of Nanosilver: Preparation and Characteristics." Journal of Polymer Research 19 (10): 6. doi:10.1007/s10965-0129980-8.

Moreno Rubio J., Jiménez López A, Barrera Lombana N. (2013). El amplificador de potencia de carga sintonizada. Revista colombiana de tecnologías de Avanzada. 2(22). Pág. 9 - 13 .

Montero, Ramon B, Ximena Vial, Dat Tat Nguyen, Sepehr Farhand, Mark Reardon, Si M Pham, Gavriil Tsechpenakis, and Fotios M Andreopoulos. 2012. "bFGF-Containing Electrospun Gelatin Scaffolds with Controlled NanoArchitectural Features for Directed Angiogenesis." Acta Biomaterialia 8 (5). Acta Materialia Inc.: 1778-91. doi:10.1016/j.actbio.2011.12.008.

Okutan, Nagihan, Pınar Terzi, and Filiz Altay. 2014. "Affecting Parameters on Electrospinning Process and Characterization of Electrospun Gelatin Nanofibers." Food Hydrocolloids $\quad 39$ (August): 19-26. doi:10.1016/j.foodhyd.2013.12.022.

Pant, Bishweshwar, Hem Raj Pant, Dipendra Raj Pandeya, Gopal Panthi, Ki Taek Nam, Seong Tshool Hong, Cheol Sang Kim, and Hak Yong Kim. 2012. "Characterization and Antibacterial Properties of Ag NPs Loaded Nylon-6 Nanocomposite Prepared by One-Step Electrospinning Process." Colloids and Surfaces A: Physicochemical and Engineering Aspects 395. Elsevier B.V.: 94-99. doi:10.1016/j.colsurfa.2011.12.011.

Pant, Hem Raj, Madhab Prasad Bajgai, Chuan Yi, R. Nirmala, Ki Taek Nam, Woo Il Baek, and Hak Yong Kim. 2010. 
"Effect of Successive Electrospinning and the Strength of Hydrogen Bond on the Morphology of Electrospun Nylon-6 Nanofibers." Colloids and Surfaces A: Physicochemical and Engineering Aspects 370 (1-3). Elsevier B.V.: 87-94. doi:10.1016/j.colsurfa.2010.08.051.

Pant, Hem Raj, Dipendra Raj Pandeya, Ki Taek Nam, Woo il Baek, Seong Tshool Hong, and Hak Yong Kim. 2011. "Photocatalytic and Antibacterial Properties of a TiO2/nylon-6 Electrospun Nanocomposite Mat Containing Silver Nanoparticles." Journal of Hazardous Materials 189 (1-2). Elsevier $\quad$ B.V.: $465-71$. doi:10.1016/j.jhazmat.2011.02.062.

Park, Suk Woo, Hyun Su Bae, Zhi Cai Xing, Oh Hyeong Kwon, Man Woo Huh, and Inn Kyu Kang. 2009. "Preparation and Properties of Silver-Containing Nylon 6 Nanofibers Formed by Electrospinning." Journal of Applied Polymer Science 112 (4): 2320-26. doi:10.1002/app.29520.

Qin, Yi, and Ioannis S. Chronakis. 2010. "Micro-/Nano-Fibers by Electrospinning Technology: Processing, Properties and Applications." In Micro-Manufacturing Engineering and Technology, 264-86. Elsevier. doi:10.1016/B978-0-81551545-6.00016-8.

Raj, Hem, Madhab Prasad, Ki Taek, Yun A Seo, Dipendra Raj, Seong Tshool, and Hak Yong. 2011. "Electrospun Nylon-6 Spider-Net like Nanofiber Mat Containing $\mathrm{TiO} 2$ Nanoparticles: A Multifunctional Nanocomposite Textile Material." Journal of Hazardous Materials 185 (1). Elsevier B.V.: 124-30. doi:10.1016/j.jhazmat.2010.09.006.

Rogina, Anamarija. 2014. "Electrospinning Process: Versatile Preparation Method for Biodegradable and Natural Polymers and Biocomposite Systems Applied in Tissue Engineering and Drug Delivery." Applied Surface Science 296 (March): 221-30. doi:10.1016/j.apsusc.2014.01.098.

Ryu, Young Jun, Hak Yong Kim, Keun Hyung Lee, Heui Chon Park, and Douk Rae Lee. 2003. "Transport Properties of Electrospun Nylon 6 Nonwoven Mats." European Polymer Journal 39 (9): 1883-89. doi:10.1016/S00143057(03)00096-X.

SCOPUS. 2017. "Scopus - Analyze Search Results." https://www-scopus-

com.itm.elogim.com:2443/term/analyzer.uri?sid=DA85696 6D6692E19D5EBE1BBCDF54542.wsnAw8kcdt7IPYLO0 $\mathrm{V} 48 \mathrm{gA} \% 3 \mathrm{~A} 70 \&$ origin $=$ resultslist $\& \mathrm{src}=\mathrm{s} \& \mathrm{~s}=\mathrm{TITLE}-\mathrm{ABS}-$ KEY\%28\%22non-

woven $\% 22+\mathrm{AND}+\% 22$ electrospinning $\% 22+\mathrm{AND}+\% 22 \mathrm{Na}$ no $\% 22+\% 29 \&$ sort=plf-f\&sdt=b\&sot=b\&sl.

Serbezeanu, Diana, Ana Maria Popa, Timea Stelzig, Ion Sava, Rene M Rossi, and Giuseppino Fortunato. 2015. "Preparation and Characterization of Thermally Stable Polyimide Membranes by Electrospinning for Protective Clothing Applications." Textile Research Journal 85 (17): 1763-75. doi:10.1177/0040517515576326.

Shi, Quan, Narendiran Vitchuli, Joshua Nowak, Jesse Noar, Jane M. Caldwell, Frederick Breidt, Mohamed Bourham, Marian McCord, and Xiangwu Zhang. 2011. "One-Step Synthesis of Silver Nanoparticle-Filled Nylon 6 Nanofibers and Their Antibacterial Properties." Journal of Materials Chemistry 21 (28): 10330. doi:10.1039/c1jm11492a.

Sill, TJ, and HA von Recum. 2008. "Electrospinning: Applications in Drug Delivery and Tissue Engineering." Biomaterials 29: 1989-2006.

Sun, B., Y.Z. Long, H.D. Zhang, M.M. Li, J.L. Duvail, X.Y. Jiang, and H.L. Yin. 2013. "Advances in ThreeDimensional Nanofibrous Macrostructures via Electrospinning." Progress in Polymer Science, June. doi:10.1016/j.progpolymsci.2013.06.002.

Vitchuli, N, Q Shi, J Nowak, K Kay, J M Caldwell, F Breidt, M Bourham, M McCord, and X W Zhang. 2011. "Multifunctional $\mathrm{ZnO} /$ Nylon 6 Nanofiber Mats by an Electrospinning-Electrospraying Hybrid Process for Use in Protective Applications." Science and Technology of
Advanced Materials 12 (5): 2-8. doi:Artn 055004/rDoi 10.1088/1468-6996/12/5/055004.

Yin, X L, M Krifa, and J H Koo. 2015. "Flame-Retardant Polyamide 6/Carbon Nanotube Nanofibers: Processing and Characterization." Journal of Engineered Fibers and Fabrics 10 (3): 1-11.

Zhang, Shu, Woo Sub Shim, and Jooyoun Kim. 2009. "Design of Ultra-Fine Nonwovens via Electrospinning of Nylon 6: Spinning Parameters and Filtration Efficiency." Materials \& Design 30 (9). Elsevier Ltd: 3659-66. doi:10.1016/j.matdes.2009.02.017.

Zhang, Yanzhong, Hongwei Ouyang, Chwee Teck Lim, Seeram Ramakrishna, and Zheng-Ming Huang. 2005. "Electrospinning of Gelatin Fibers and gelatin/PCL Composite Fibrous Scaffolds." Journal of Biomedical Materials Research. Part B, Applied Biomaterials 72 (1): 156-65. doi:10.1002/jbm.b.30128.

Zhuo, Haitao, Jinlian Hu, and Shaojun Chen. 2008. "Electrospun Polyurethane Nanofibres Having Shape Memory Effect." Materials Letters 62 (14): 2074-76. doi:10.1016/j.matlet.2007.11.018. 